\title{
PENGARUH CORPORATE SOCIAL RESPONSIBILITY (CSR), KEBERADAAN WHISTLEBLOWING INTERNAL, DAN KOMITMEN GOOD COORPORATE GOVERNANCE (GCG) TERHADAP GOING CONCERN PERUSAHAAN (STUDI PADA SEKTOR PERHOTELAN YANG TERDAFTAR DI BEI)
}

\author{
a Gine Das Prena, bPutu Viona Prameswari Dewi \\ Universitas Pendidikan Nasional \\ ginedasfrena@undiknas.ac.id
}

\begin{abstract}
ABSTRAK
Keberlanjutan Usaha

(Going Concern)

merupakan sebuah asumsi bahwa suatu perusahaan akan terus menjalankan bisnisnya dimasa mendatang. Keberlanjutan usaha akan tetap terjamin jika perusahaan memperhatikan dimensi seperti sosial dan lingkungan hidup. Penelitian ini bertujuan untuk mengetahui bagaimana Corporate Social Responsibility (CSR), Keberadaan Whistleblowing Internal, Komitmen Good Corporate Governance (GCG) berpengaruh terhadap Going Concern Perusahaan (Studi Pada Sektor Perhotelan yang Terdaftar di BEI). Penelitian ini menggunakan sumber data sekunder, dengan menggunakan laporan keuangan perhotelan yang terdaftar di BEl. Populasi yang digunakan dala penelitian ini sebanyak 18 perhotelan dengan periode 2015-2019 dan sampel sebanyak 90 data. Metode yang digunakan adalah analisis kuantitatif yaitu analisis linier berganda dengan menggunakan alat uji SPSS. Hasil uji $t$ menunjukan bahwa Corporate Social Responsibility (CSR), Keberadaan Whistleblowing Internal, Komitmen Good Corporate Governance (GCG) masing-masing berpengaruh positif terhadap Going Concern. Koefisien Determinasi $\left(\boldsymbol{R}^{2}\right)$ nilainya sebesar 0,616 yang berarti besar pengaruh variabel bebas terhadap variabel terikatnya adalah $0,616 \times 100 \%=61,6 \%$ sedangkan sebesar $38,4 \%$ dijelaskan oleh faktorfaktor lain yang tidak diuji dalam penelitian ini.
\end{abstract}

Kata Kunci: Corporate Social Responsibility (CSR), Keberadaan Whistleblowing Internal, Good Corporate Governanance (GCG), Going Concern.

\section{ABSTRACT}

Going Concern is an assumption that an entity will remain in business in the future. Business sustainability will only be guaranteed when paying attention to the social and environmental dimensions. This research aims to find out if Corporate Social Responsibility (CSR), The Existence of Internal Whistleblowing, Good Corporate Governance (GCG) Commitment affects Corporate Going Concern (Study on Hospitality Sector Registered in IDX). The study used a secondary data source, using hospitality financial statements listed on IDX. The population used in this study was 18 hospitality with the period 2015-2019 and the sample used as many as 90 data. The method of analysis used is quantitative analysis which is multiple linear analysis using spss test tool. $T$ test results showed that Corporate Social Responsibility (CSR), The Existence of Internal Whistleblowing, Good Corporate Governance (GCG) commitment each had a positive effect on Going Concern. The Determination Coefficient $\left(R^{\wedge} 2\right)$ is 0.616 which means the effect of free variables on their bound variables is $0.616 \times 100 \%=61.6 \%$ while $38.4 \%$ is explained by other factors not tested in this study. 
Keywords: Corporate Social Responsibility (CSR), Internal Whistleblowing Existence, Good Corporate Governance (GCG), Going Concern.

\section{PENDAHULUAN}

Dewasa ini, keberadaan akomodasi pariwisata khususnya perhotelan, tentu dapat memberikan lapangan pekerjaan bagi masyarakat sekitar. Perusahaan perhotelan dalam menjalankan bisnisnya tidak hanya untuk menghasilkan keuntungan, tetapi juga bertujuan untuk menjaga kelangsungan hidup perusahaan (Going concern). Going concern adalah kemampuan perusahaan mempertahankan kelangsungan hidupnya. Apabila suatu laporan keuangan disusun dengan dasar going concern, berarti dapat diartikan bahwa perusahaan tersebut berharap bertahan dalam jangka waktu yang panjang. Pada perhotelan salah satu hal yang menjadi hambatan dalam keberlangsungan hidup perusahaan (going concern) adalah persaingan industri hotel yang ditandai dengan banyaknya pembangunan hotel yang akan menyebabkan alih fungsi lahan seperti pertanian, perkebunan dan hutan menjadi hotel (Sari dkk, 2017).

Banyaknya hotel yang muncul menimbulkan dampak-dampak seperti turunnya debit air, pencemaran lingkungan dan lainnya dari segi ekonomi, sosial, maupun lingkungan. Untuk menjaga keberlangsungan hidup perusahaan (going concern) perhotelan harus mengurangi dampak negatif yang dihasilkan, dapat dilakukan dengan penerapan CSR. Melalui CSR, perhotelan juga dapat menunjukkan kepeduliannya untuk lingkungan dan masyarakat. Penerapan CSR dapat menurunkan biaya keagenan suatu perusahaan. Setelah perusahaan menerapkan CSR, terjadi pengurangan biaya agen yang dikeluarkan akibat pemasaran produk lalu menggantinya dengan biaya CSR. Meskipun perusahaan harus mengeluarkan biaya untuk pertanggung jawaban pada lingkungan sekitar hotel, tetapi nantinya akan memberikan pengaruh terhadap kegiatan promosi dan menjaga going concern perusahaan.

Selanjutnya, pelaksanaan whistleblowing dapat menurunkan biaya keagenan. Pelaporan tindak kecurangan dalam sebuah perusahaan dapat mengurangi biaya keagenan dalam menangani hal yang diakibatkan dari terjadinya pelanggaran, dengan berkurangnya biaya keagenan tersebut maka hal ini dapat mendukung going concern perusahaan. Menurut Brandon (2013) Whistleblowing internal terjadi saat seseorang atau lebih karyawan mengetahui tindak kecurangan yang dilakukan oleh karyawan lain atau dilakukan oleh kepala bagiannya, kemudian karyawan tersebut melaporkan kecurangan itu kepada pimpinan perusahaan yang memiliki jabatan lebih tinggi. Whistleblowing adalah kebijakan yang membutuhkan karyawan untuk melaporkan berbagai pelanggaran yang mereka temukan di dalam perusahaan. Mahkamah Agung melalui Surat Edaran Mahkamah RI Nomor 4 Tahun 2011 menerjemahkan whistleblower adalah pelaportindak pidana yang mengetahui kemudian melaporkan tindak pidana tersebut dan pelaporan tersebut bukan merupakan pelaku kejahatan yang dilaporkannya (wbs.menpan.go.id/).

Selanjutnya, faktor lain yang dapat menjaga going concern suatu perusahaan adalah dengan menerapkan Good Coporate Governance (GCG). Seorang pemilik perusahaan dan pemegang saham terkadang hanya menginginkan hasil akhiri yaitu memperoleh laba yang tinggi. Sedangkan manajer memiliki tujuan untuk mendapatkan gaji yang tinggi pula untuk mengganti kontribusi atas apa yang diberikan pada perusahaan. Adanya perbedaan dari kepentingan ini yang menimbulkan terjadinya biaya keagenan. Dengan perusahaan menerapkan Good Corporate Governance secara berkomitmen juga dapat memberikan perlindungan pada pemegang saham ataupun kreditur untuk menjamin pengembalian atas investasi yang diberikan dengan hasil yang tinggi. 


\section{Agency Theory}

\section{KAJIAN LITERATUR}

Dalam teori keagenan menerangkan bahwa dua pelaku ekonomi yang saling bertentangan yaitu mengenai prinsipal dan agen. Hubungan keagenan adalah suatu kontrak dimana satu orang atau lebih prinsipal memerintah orang lain atau agen untuk melakukan suatu jasa dan menyerahkan wewenang kepada agen untuk membuat keputusan yang terbaik bagi prinsipal dan perusahaan (Ichsan, 2014).

\section{Tripple Bottom Line Theory}

Triple Bottom Line adalah pengukuran kinerja suatu perusahaan secara holistik dengan memperhatikan ukuran kinerja perusahaan berupa perolehan profit, ukuran kepedulian social antar sesama, dan ukuran pelestarian lingkungan. Konsep Tripple Bottom Line (People, Planet, and Profit) merupakan konsep bisnis dan aktivitas ekonomi yang berbeda.

\section{Going Concern}

Keberlanjutan Usaha (Going Concern) merupakan asumsi bahwa suatu perusahaan akan tetap menjalankan usahanya di masa yang akan datang. Entitas tidak akan mengalami keterpaksaan untuk menghentikan operasinya dan melikuidasi asetnya dalam waktu dekat. Keberlanjutan usaha hanya akan terjamin apabila memperhatikan dimensi sosial dan lingkungan hidup.

\section{Corporate Social Responsibility (CSR)}

Berdasarkan pengertian yang dikemukakan oleh para ahli CSR adalah suatu komitmen berkelanjutan oleh dunia usaha untuk bertindak etis dan memberikan kontribusi kepada pengembangan ekonomi dari komunitas setempat atau masyarakat luas, bersaman dengan peningkatan taraf hidup pekerja beserta keluarganya

\section{Whistleblowing}

Whistleblowing merupakan tindakan yang dilakukan oleh seseorang atau beberapa orang karyawan untuk membocorkan kecurangan baik yang dilakukan oleh perusahaan atau atasannya kepada pihak lain. Menurut Komite Nasional Kebijakan Governance (KNKG) menyatakan bahwa whistleblowing pada umumnya dilakukan secara rahasia (confidential).

\section{Good Corporate Governance (GCG)}

Munurut Forumfor Governance in Indonesia (FCGI), Good Corporate Governance adalah seperangkat aturan yang menetapkan hubungan antara pemegang saham, pengurus, kreditur, pemerintah, karyawan serta para pemegang kepentingan (stakeholders) sehubungan dengan hak-hak dan kewajiban mereka, atau dapat dikatakan sebagai suatu system yang mengarahkan dan mengendalikan perusahaan.

\section{Hipotesis Penelitian}

H1: Corporate Social Responsibility berpengaruh positif terhadap going concern perusahaan.

H2: Keberadaan whistleblowing internal berpengaruh positif terhadap going concern perusahaan.

H3: Komitmen Good Corporate Governance (GCG) berpengaruh positif terhadap going concern perusahaan.

H4: Corporate Social Responsibility (CSR), Keberadaan Whistleblowing Internal dan Komitmen Good Corporate Governance (GCG) berpengaruh positif terhadap going concern perusahaan.

\section{METODE}




\section{Populasi dan Sampel Penelitian}

Populasipada penelitian adalah perusahaan perhotelan yang terdaftar di Bursa Efek Indonesia (BEl) periode 2015-2019. Jumlah polulasi 34 perusahaan perhotelan. Diperoleh sebanyak 18 perhotelan yang memenuhi syarat sebagai sampel penelitian dengan metode purposive sampling.

Jumlah sampel penelitian yang memenuhi kriteria: 18 perusahaan Interval periode yang digunakan: 2015-2019 (5 tahun) Total observasi penelitian: 18 perusahaan $\times 5$ tahun $=90$ data Sehingga dalam penelitian ini data yang dibutuhkan sebanyak 90 data.

\section{Teknik Pengumpulan Data}

Teknik pengumpulan data yang digunakan dalam penelitian ini adalah berupa time series. Data bersifat time series karena data dalam penelitian ini adalah annual report dalam interval waktu tertentu yaitu tahun 2015-2019 yang diakses melalui web www.idx.co.id.

\section{Teknik Analisis Data}

Pengujian instrument penelitian ini menggunakan Corporate Social Responsibility Index (CSRI), Whistleblowing System (WBS), Good Corporate Index (GCI), dan Price Book Value (PBV), selanjutnya dilakukan uji deskriptif, asumsi klasik, uji regresi liner berganda dan uji kelayakan model.

\section{HASIL DAN PEMBAHASAN}

Pengujian instrument penelitian ini menggunakan Corporate Social Responsibility Index (CSRI), Whistleblowing System (WBS), Good Corporate Index (GCl), dan Price Book Value (PBV).

\section{Tabulasi Data}

\begin{tabular}{|c|c|c|c|c|c|c|c|}
\hline No & Code & Description & Tahun & $\mathbf{X} 1$ & $\mathrm{X} 2$ & X3 & $\mathbf{Y}$ \\
\hline \multirow[t]{5}{*}{1} & \multirow[t]{5}{*}{ SSIA } & \multirow{5}{*}{$\begin{array}{l}\text { PT. Surya Semesta Internusa } \\
\text { Tbk. }\end{array}$} & 2015 & 0 & 75 & 15 & 0,52 \\
\hline & & & 2016 & 0 & 75 & 13 & 0,28 \\
\hline & & & 2017 & 0 & 75 & 14 & 0,27 \\
\hline & & & 2018 & 1 & 75 & 13 & 0,31 \\
\hline & & & 2019 & 1 & 75 & 13 & 0,25 \\
\hline \multirow[t]{5}{*}{2} & \multirow[t]{5}{*}{ SHID } & \multirow{5}{*}{$\begin{array}{l}\text { PT. Sahid Jaya International } \\
\text { Tbk. }\end{array}$} & 2015 & 0 & 25 & 12 & 0,18 \\
\hline & & & 2016 & 0 & 25 & 13 & 0,69 \\
\hline & & & 2017 & 1 & 75 & 14 & 1,14 \\
\hline & & & 2018 & 1 & 75 & 13 & 1,20 \\
\hline & & & 2019 & 1 & 75 & 13 & 2,73 \\
\hline \multirow[t]{5}{*}{3} & \multirow[t]{5}{*}{ HOTL } & \multirow[t]{5}{*}{ PT. Saraswati Driya Lestari Tbk. } & 2015 & 0 & 0 & 7 & 0,17 \\
\hline & & & 2016 & 0 & 75 & 8 & 3,17 \\
\hline & & & 2017 & 0 & 75 & 8 & 3,09 \\
\hline & & & 2018 & 1 & 75 & 7 & 3,15 \\
\hline & & & 2019 & 1 & 75 & 7 & 3,71 \\
\hline \multirow[t]{5}{*}{4} & \multirow[t]{5}{*}{ INPP } & \multirow{5}{*}{$\begin{array}{l}\text { PT. Indonesia Paradise Property } \\
\text { Tbk. }\end{array}$} & 2015 & 1 & 75 & 11 & 2,04 \\
\hline & & & 2016 & 1 & 75 & 12 & 1,53 \\
\hline & & & 2017 & 1 & 75 & 12 & 0,17 \\
\hline & & & 2018 & 1 & 75 & 12 & 1,09 \\
\hline & & & 2019 & 1 & 75 & 15 & 0,19 \\
\hline \multirow[t]{3}{*}{5} & \multirow[t]{3}{*}{ TARA } & \multirow[t]{3}{*}{ PT. Sitara Propertindo Tbk. } & 2015 & 1 & 50 & 7 & 0,81 \\
\hline & & & 2016 & 1 & 75 & 7 & 1,22 \\
\hline & & & 2017 & 1 & 75 & 8 & 1,09 \\
\hline
\end{tabular}




\begin{tabular}{|c|c|c|c|c|c|c|c|}
\hline & & & 2018 & 1 & 75 & 7 & 1,12 \\
\hline & & & 2019 & 1 & 75 & 7 & 1.17 \\
\hline \multirow[t]{5}{*}{6} & \multirow[t]{5}{*}{ PWON } & \multirow{5}{*}{ PT. Pakuwon Jati Tbk. } & 2015 & 1 & 50 & 12 & 1,27 \\
\hline & & & 2016 & 1 & 75 & 12 & 1,31 \\
\hline & & & 2017 & 1 & 75 & 12 & 1,41 \\
\hline & & & 2018 & 1 & 75 & 11 & 1,19 \\
\hline & & & 2019 & 1 & 75 & 12 & 0,16 \\
\hline \multirow[t]{5}{*}{7} & \multirow[t]{5}{*}{ JIHD } & \multirow{5}{*}{$\begin{array}{l}\text { PT. Jakarta International Hotel \& } \\
\text { Development Tbk. }\end{array}$} & 2015 & 1 & 75 & 13 & 0,21 \\
\hline & & & 2016 & 1 & 75 & 13 & 1,73 \\
\hline & & & 2017 & 1 & 75 & 13 & 1.60 \\
\hline & & & 2018 & 1 & 75 & 16 & 0,15 \\
\hline & & & 2019 & 1 & 75 & 15 & 0,13 \\
\hline \multirow[t]{5}{*}{8} & \multirow[t]{5}{*}{ EAST } & \multirow[t]{5}{*}{ PT. Eastparc Hotel Tbk. } & 2015 & 1 & 25 & 7 & 1,05 \\
\hline & & & 2016 & 1 & 25 & 8 & 1,19 \\
\hline & & & 2017 & 1 & 25 & 8 & 1,59 \\
\hline & & & 2018 & 1 & 50 & 8 & 1,31 \\
\hline & & & 2019 & 1 & 75 & 9 & 1,27 \\
\hline \multirow[t]{5}{*}{9} & \multirow[t]{5}{*}{ BUVA } & \multirow[t]{5}{*}{ PT. Bukit Uluwatu Villa Tbk. } & 2015 & 1 & 0 & 12 & 0,15 \\
\hline & & & 2016 & 1 & 75 & 13 & 6,45 \\
\hline & & & 2017 & 1 & 75 & 13 & 5,61 \\
\hline & & & 2018 & 1 & 75 & 11 & 0,52 \\
\hline & & & 2019 & 1 & 75 & 13 & 0,43 \\
\hline \multirow[t]{5}{*}{10} & \multirow[t]{5}{*}{ TBIG } & \multirow{5}{*}{$\begin{array}{l}\text { PT. Tower Bersama Infrastruktur } \\
\text { Tbk. }\end{array}$} & 2015 & 1 & 0 & 13 & 2,23 \\
\hline & & & 2016 & 1 & 0 & 13 & 1,88 \\
\hline & & & 2017 & 1 & 50 & 12 & 1,13 \\
\hline & & & 2018 & 1 & 75 & 12 & 0,55 \\
\hline & & & 2019 & 1 & 75 & 12 & 1,80 \\
\hline \multirow[t]{5}{*}{11} & \multirow[t]{5}{*}{ HOME } & \multirow{5}{*}{$\begin{array}{l}\text { PT. Hotel Mandarin Regency } \\
\text { Tbk. }\end{array}$} & 2015 & 1 & 0 & 8 & 6,11 \\
\hline & & & 2016 & 1 & 0 & 8 & 5,71 \\
\hline & & & 2017 & 1 & 0 & 8 & 2,62 \\
\hline & & & 2018 & 1 & 75 & 9 & 2,61 \\
\hline & & & 2019 & 1 & 75 & 9 & 1,28 \\
\hline \multirow[t]{5}{*}{12} & GMCW & PT. Grahamas Citrawisata Tbk. & 2015 & 0 & 0 & 16 & 1,18 \\
\hline & & & 2016 & 0 & 25 & 11 & 1,27 \\
\hline & & & 2017 & 1 & 25 & 15 & 1,31 \\
\hline & & & 2018 & 1 & 25 & 16 & 1,34 \\
\hline & & & 2019 & 1 & 25 & 12 & 1,40 \\
\hline 13 & SATU & PT. Kota Satu Properti Tbk. & 2015 & 0 & 75 & 6 & 2,21 \\
\hline & & & 2016 & 0 & 75 & 6 & 2,58 \\
\hline & & & 2017 & 1 & 75 & 6 & 2,58 \\
\hline & & & 2018 & 1 & 75 & 6 & 2,21 \\
\hline & & & 2019 & 1 & 75 & 7 & 2,58 \\
\hline 14 & FITT & PT. Hotel Fitra International Tbk. & 2015 & 1 & 0 & 7 & 1,05 \\
\hline & & & 2016 & 1 & 25 & 7 & 1,93 \\
\hline & & & 2017 & 1 & 25 & 8 & 1,41 \\
\hline & & & 2018 & 1 & 50 & 8 & 1,31 \\
\hline & & & 2019 & 1 & 75 & 8 & 1,27 \\
\hline 15 & HRME & PT. Menteng Heritage Realty & 2015 & 0 & 0 & 9 & 0,74 \\
\hline & & & 2016 & 0 & 50 & 9 & 0,73 \\
\hline & & & 2017 & 0 & 50 & 10 & 6,37 \\
\hline & & & 2018 & 0 & 75 & 10 & 0,73 \\
\hline & & & 2019 & 1 & 75 & 11 & 5,46 \\
\hline
\end{tabular}




\begin{tabular}{|c|c|c|c|c|c|c|c|}
\hline \multirow[t]{5}{*}{16} & \multirow[t]{5}{*}{ TOTL } & \multirow[t]{5}{*}{ PT. Total Bangun Persada Tbk. } & 2015 & 1 & 75 & 18 & 0,16 \\
\hline & & & 2016 & 1 & 75 & 18 & 0,15 \\
\hline & & & 2017 & 1 & 75 & 14 & 0,18 \\
\hline & & & 2018 & 1 & 75 & 17 & 5,85 \\
\hline & & & 2019 & 1 & 75 & 16 & 4,93 \\
\hline \multirow[t]{5}{*}{17} & \multirow[t]{5}{*}{ PSKT } & \multirow[t]{5}{*}{ PT. Red Planet Indonesia Tbk. } & 2015 & 1 & 75 & 15 & 0,15 \\
\hline & & & 2016 & 1 & 75 & 15 & 1,13 \\
\hline & & & 2017 & 1 & 75 & 14 & 0,16 \\
\hline & & & 2018 & 1 & 75 & 14 & 0,15 \\
\hline & & & 2019 & 1 & 75 & 14 & 1,11 \\
\hline \multirow[t]{5}{*}{18} & \multirow[t]{5}{*}{ JSPT } & \multirow{5}{*}{$\begin{array}{lr}\text { PT. Jakarta } \\
\text { International Tbk. }\end{array}$} & 2015 & 1 & 0 & 14 & 3,15 \\
\hline & & & 2016 & 1 & 0 & 13 & 2,98 \\
\hline & & & 2017 & 1 & 0 & 13 & 2,18 \\
\hline & & & 2018 & 1 & 25 & 13 & 4,45 \\
\hline & & & 2019 & 1 & 25 & 13 & 4,25 \\
\hline
\end{tabular}

Uji Deskriptif memberikan gambaran atau deskripsi suatu data yang dilihat dari nilai ratarata (mean), standar deviasi, maksimum, dan minimum dari masing-masing variabel, (Ghozali, 2016).

Tabel 4.1

Descriptive Statistics

\begin{tabular}{|l|r|r|r|r|r|}
\hline & N & Minimum & Maximum & \multicolumn{1}{|c|}{ Mean } & Std. Deviation \\
\hline CSR & 90 & 0 & 1 &, 61 &, 490 \\
Whistleblowing Internal & 90 & 15 & 100 & 56,50 & 28,830 \\
GCG & 90 & 6 & 21 & 12,20 & 3,849 \\
Going Concern & 90 &, 21 & 20,00 & 4,4237 & 5,59913 \\
Valid N (listwise) & 90 & & & & \\
\hline
\end{tabular}

Berdasarkan table statistik deskriptif diatas, dapat dijelaskan sebagai berikut:

1. Variabel CSR pada tabel 4.1 menunjukkan nilai minimum sebesar 0,00 dan nilai maksimum sebesar 1 dengan nilai rata-rata 0,61 dan standar deviasi sebesar 0,4900 dimana nilai standar deviasi ini lebih kecil dari rata-rata yang menunjukkan bahwa penerapan CSR memiliki fluktuasi yang kecil.

2. Variabel Whistleblowing Internal pada tabel 4.1 menunjukkan nilai minimum 15 dan nilai maksimum 100 dengan rata-rata sebesar 56.500 dan standar deviasi 28.830 dimana nilai standar deviasi ini lebih kecil dari rata-rata yang menunjukkan bahwa Whistleblowing Internal memiliki fluktuasi yang kecil.

3. Variabel GCG Internal pada tabel 4.1 menunjukkan nilai minimum 6.000 dan nilai maksimum 21 dengan rata-rata sebesar 12.20 dan standar deviasi 3.849 dimana nilai standar deviasi ini lebih kecil dari rata-rata yang menunjukkan bahwa GCG memiliki fluktuasi yang kecil.

4. Variabel Going Concern memiliki rata-rata sebesar 0.21 dengan standar deviasi 5.59913 dimana nilai standar deviasi lebih besar dari ratarata menunjukkan bahwa Going Concern memiliki fluktuasi yang besar. Going Concern terendah sebesar 0.21 sedangkan nilai tertinggi sebesar 20.00.

Uji asumsi klasik dalam penelitian ini yaitu uji normalitas dan uji heteroskedastisitas. Uji normalitas dalam penelitian ini menggunakan uji statistik non-parametrik One Sample Kolmogorov-Smirnov Test. Residual berdistribusi normal apabila Asymp.Sig. lebih besar dari a 0,05 (Ghozali, 2016). Hasil uji normalitas disajikan pada 
Tabel 4.2.

One-Sample Kqlabep4.2Smirnov Test

\begin{tabular}{|ll|r|}
\hline & & $\begin{array}{r}\text { Unstandardiz } \\
\text { ed Residual }\end{array}$ \\
\hline Normal Parameters & a,b & Mean \\
Most Extreme Differences & Std. Deviation &, 0000000 \\
& Absolute & 3,41059788 \\
& Positive &, 061 \\
Kolmogorov-Smirnov Z & Negative &, 061 \\
Asymp. Sig. (2-tailed) & &,- 046 \\
\end{tabular}

a. Test distribution is Normal.

b. Calculated from data.

Berdasarkan Tabel 4.2

menunjukkan bahwa

unstandardized residual dalam penelitian ini memiliki nilai Asymp.Sig. (2-tailed) sebesar 0,895 yang lebih besar dari taraf signifikansi 0,05 . Hal ini berarti seluruh data berdistribusi normal.

Uji multikolinearitas dilakukan untuk mengetahui adanya korelasi antar variabel independen dalam suatu model regresi. Uji multikolinearitas menggunakan Variance Inflation Factor (VIF). Hasil uji multikolinearitas dapat dilihat pada table 4.3

Tabel 4.3

Coefficients $^{\mathrm{a}}$

\begin{tabular}{|ll|r|r|}
\hline \multirow{2}{*}{ Model } & \multicolumn{2}{|c|}{ Collinearity Statistics } \\
\cline { 3 - 4 } & & Tolerance & \multicolumn{1}{c|}{ VIF } \\
\hline & CSR &, 938 & 1,066 \\
& Whistleblowing Internal &, 978 & 1,022 \\
& GCG &, 938 & 1,066 \\
\hline
\end{tabular}

a. Dependent Variable: Going Concern

Tabel 4.3 Berdasarkan output SPSS diperoleh nilai tolerance berturut-turut sebesar 0,$938 ; 0,978 ; 0,938$, yang kesemuanya lebih besar dari 10 persen $(0,10)$, dan nilai VIF sebesar 1,066; 1,022; 1,066 yang kesemuanya lebih kecil $<10$. Hal ini berarti model regresi tersebut lolos uji multikolinearitas.

Pengujian heteroskedastisitas dalam penelitian ini menggunakan uji Glejser. Tingkat probabilitas signifikansi masing-masing variabel bebas jika lebih besar dari 0,05 maka dapat disimpulkan tidak terdapat heteroskedastisitas (Ghozali, 2016:138). Hasil uji heteroskedastisitas disajikan pada Tabel 4.4.

\section{Tabel 4.4}


Coefficients ${ }^{a}$

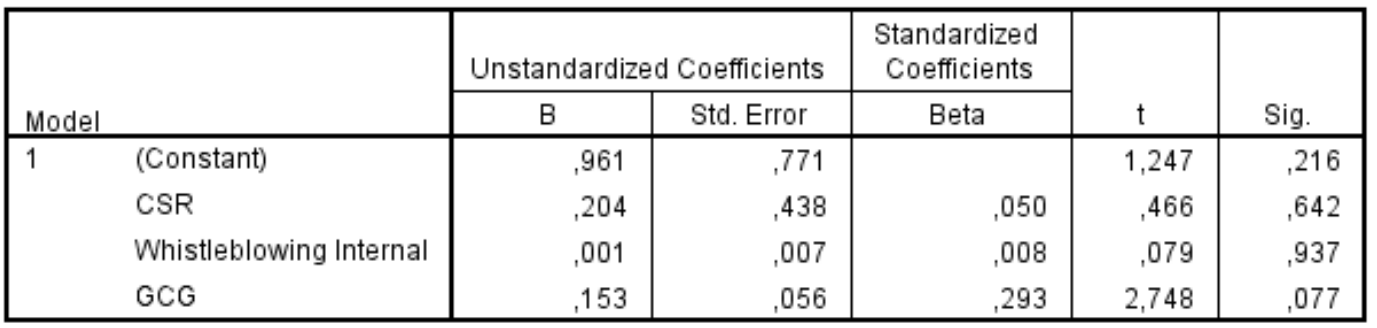

a. Dependent Variable: ABS_Res

Hasil uji Gletser diperoleh nilai signifikansi variabel sikap CSR sebesar 0, 642, variabel Whistleblowing Internal 0,937, variabel GCG sebesar 0,077, semua nilai sig pada tiga variabel bebas lebih besar $>0,05$. Hal ini berarti model regresi tersebut tidak mengandung gejala heteroskedastisitas.

Uji autokorelasi bertujuan untuk menguji apakah dalam suatu model regresi linear terdapat korelasi antara kesalahan pengganggu pada periode tdengan kesalahan pengganggu periode $\mathrm{t}-1$, untuk melihat ada tidaknya besaran autokorelasi dapat digunakan besaran Durbin Watson (D-W) pada output pengujian (Ghozali, 2018:107). Jika nilai (D-W) test sudah ada, nilai tersebut dibandingkan dengan nilai table dengan menggunakan tingkat keyakinan sebesar 95 persen:

1. Bila du $<\mathrm{dw}<4$-du, maka tidak terjadi autokorelasi;

2. Bila $d w<d l$, berarti terjadi autokorelasi positif;

3. Bila $d w>4-d l$, berarti terjadi autokorelasi negatif;

4. Bila dl $<d w<d u$ atau 4-du $<d w<4$ 4d, maka tidak dapat disimpulkan mengenai ada tidaknya autokorelasi

Tabel 4.5

Model Summary ${ }^{b}$

\begin{tabular}{|l|l|r|r|r|r|}
\hline Model & $\mathrm{R}$ & R Square & $\begin{array}{c}\text { Adjusted R } \\
\text { Square }\end{array}$ & $\begin{array}{c}\text { Std. Error of } \\
\text { the Estimate }\end{array}$ & $\begin{array}{c}\text { Durbin- } \\
\text { Watson }\end{array}$ \\
\hline 1 &, $793^{\mathrm{a}}$ &, 629 &, 616 & 3,46958 & 1,907 \\
\hline
\end{tabular}

a. Predictors: (Constant), GCG, Whistleblowing Internal, CSR

b. Dependent Variable: Going Concern

Dari tabel diatas hasil perhitungan diatas bahwa nilai DW sebesar 1,907 terletak diantara nilai du dan (4-du) sebesar 1,7264 dan 2,2736 (du < DW < 4-du) maka dapat disimpulkan bahwa tidak terdapat autokorelasi positif dalam model regresi yang digunakan.

\section{Analisis regresi linier berganda}

Tabel 4.6

Hasil Regresi Linear Berganda

\begin{tabular}{|c|c|c|c|}
\hline \multirow[b]{2}{*}{ Mode } & & \multicolumn{2}{|c|}{ Unstandardized Coefficients } \\
\hline & & $\mathrm{B}$ & Std. Error \\
\hline \multirow[t]{4}{*}{1} & (Constant) & $-11,211$ & 1,364 \\
\hline & CSR & 2,427 &, 775 \\
\hline & Whistleblowing Internal &, 055 &, 013 \\
\hline & GCG & ,908 &, 099 \\
\hline
\end{tabular}

a. Dependent Variable: Going Concern

Berdasarkan Tabel 4.6 diperoleh suatu persamaan regresi berganda sebagai berikut. 


$$
Y=-11,211+2,427+0,055+0,908+\varepsilon
$$

1. Nilai konstanta sebesar $-11,211$ mempunyai arti bahwa jika semua variabel bebas (CSR (X1), Whistleblowing Internal (X2) dan GCG (X3)), naik satu satuan mengakibatkan nilai dari Going Concern $(Y)$ pada perusahaan perhotelan yang terdaftar di BEI turun sebesar 11,211 satuan.

2. Nilai koefisien regresi CSR (X1) sebesar 2,427 berartibila CSR meningkat sebesar satu persen menyebabkan Going Concern (Y) pada perusahaan perhotelan yang terdaftar di BEI akan meningkat sebesar 2,427 satuan, dengan asumsi faktor lainnya konstan.

3. Nilai koefisien regresi Whistleblowing Internal (X2) sebesar 0,055 berarti bila Whistleblowing Internal meningkat sebesar satu persen menyebabkan Going Concern ( $\mathrm{Y}$ ) pada perusahaan perhotelan yang terdaftar di BEl akan meningkat sebesar akan meningkat sebesar 0,055 satuan, dengan asumsi faktor lainnya konstan.

4. Nilai koefisien regresi GCG (X3) sebesar 0,908 berartibila GCG meningkat sebesar satu persen menyebabkan Going Concern (Y) pada perusahaan perhotelan yang terdaftar di BEI akan meningkat sebesar 0,908 satuan, dengan asumsi faktor lainnya konstan.

Uji kelayakan model yang digunakan dalam penelitian ini yaitu uji koefisien determinasi, uji f, dan uji t,. Hasil uji koefisien determinasi dalam penelitian ini disajikan pada Tabel 4.7 sebagai berikut:

Tabel 4.7

Koefisien Determinasi

\begin{tabular}{|l|l|r|r|r|}
\hline Model & $\mathrm{R}$ & $\mathrm{R}$ Square & $\begin{array}{c}\text { Adjusted R } \\
\text { Square }\end{array}$ & $\begin{array}{c}\text { Std. Error of } \\
\text { the Estimate }\end{array}$ \\
\hline 1 &, $793^{\text {a }}$ &, 629 &, 616 & 3,46958 \\
\hline
\end{tabular}

a. Predictors: (Constant), GCG, Whistleblowing Internal, CSR

Berdasarkan Tabel 4.7 Berdasarkan table 4.7, dapat dilihat bahwa nilai koefesien determinasi pada kolom Adjusted $R$ Square sebesar 0,616, atau sebesar 61,6 persen. Hal ini menunjukkan besarnya pengaruh variabel Corporate Social Responsibility (CSR), Keberadaan Whistleblowing Internal dan Good Corporate Governance (GCG) terhadap Going Concern adalah sebesar 61,6 persen dan besarnya variabel lain yang mempengaruhi Going Concern diluar model regresi adalah $(100 \%-61,6 \%=38,4 \%)$ sebesar 38,4 persen. Hasil uji $F$ dalam penelitian ini disajikan pada Tabel 4.8. sebagai berikut: 
Tabel 4.8

Hasil Uji Regresi Simultan (Uji-F)

\begin{tabular}{|c|c|c|c|c|c|c|}
\hline \multicolumn{7}{|c|}{ ANOVA $^{a}$} \\
\hline \multicolumn{2}{|c|}{ Model } & $\begin{array}{l}\text { Sum of } \\
\text { Squares }\end{array}$ & df & Mean Square & $\mathrm{F}$ & Sig. \\
\hline \multirow[t]{3}{*}{1} & Regression & 1754,912 & 3 & 584,971 & 48,594 &, $000^{b}$ \\
\hline & Residual & 1035,264 & 86 & 12,038 & & \\
\hline & Total & 2790,176 & 89 & & & \\
\hline
\end{tabular}

a. Dependent Variable: Going Concern

b. Predictors: (Constant), GCG, Whistleblowing Internal, CSR

Berdasarkan Tabel 4.8 yaitu, nilai $F$ hitung sebesar 48,594 dengan signifikansi sebesar 0,000 lebih kecil dari $\alpha=0,05$. Hasil ini menunjukkan bahwa model regresi dapat digunakan untuk memprediksi Going Concern. Nilai signifikansi yang lebih kecil dari $\alpha=0,05$ menunjukkan bahwa Corporate Social Responsibility (CSR), Keberadaan Whistleblowing Internal dan Good Corporate Governance (GCG) secara simultan berpengaruh signifikan terhadap Going Concern.

Uji hipotesis (ujit) dalam penelitian ini menggunakan Level of significant (a) sebesar $5 \%$. $H_{i}$ diterima jika $p$-value $\alpha \alpha=0,05$. Berdasarkan Tabel 4.9 hasil pengujian pengaruh masing-masing variabel
dapat dijabarkan sebagai berikut. bebas terhadap variabel terikat

Tabel 4.9

Hasil Uji Regresi Parsial (Uji-t)

Coefficients $^{\mathrm{a}}$

\begin{tabular}{|c|c|c|c|c|c|c|}
\hline \multirow{2}{*}{\multicolumn{2}{|c|}{ Model }} & \multicolumn{2}{|c|}{ Unstandardized Coefficients } & \multirow{2}{*}{$\begin{array}{c}\begin{array}{c}\text { Standardized } \\
\text { Coefficients }\end{array} \\
\text { Beta } \\
\end{array}$} & \multirow[b]{2}{*}{ I } & \multirow[b]{2}{*}{ Sig. } \\
\hline & & $B$ & Std. Error & & & \\
\hline \multirow[t]{4}{*}{1} & (Constant) & $-11,211$ & 1,364 & & $-8,219$ &, 000 \\
\hline & CSR & 2,427 & ,775 &, 212 & 3,133 &, 002 \\
\hline & Whistleblowing Internal & 055 &, 013 & 281 & 4,225 &, 000 \\
\hline & GCG & ,908 & 099 & 624 & 9,199 &, 000 \\
\hline
\end{tabular}

a. Dependent Variable: Going Concern

Berdasarkan Tabel 4.10 yaitu, uji regresi parsial (uji t) menunjukan bahwa:

1. Pengaruh Corporate Social Responsibility (CSR) Terhadap Going Concern Perusahaan.

Uji-t digunakan untuk menguji masing koefisien regresi, sehingga

signifikansi masingsecara parsial Corporate Social Responsibility (CSR) terhadap going concern perusahaan adalah memang nyata terjadi (signifikan) atau hanya diperoleh secara kebetulan. Langkah-langkah uji statistiknya adalah sebagai berikut:

a) Membuat Formulasi Hipotesis

$\mathrm{H}_{0}: \beta_{1}=0 \quad$ Berarti bahwa tidak ada pengaruh yang nyata antara Corporate Social Responsibility (CSR) (X1) terhadap going concern perusahaan $(\mathrm{Y})$.

$\mathrm{Ha}: \beta_{1}>0$ Berarti bahwa ada pengaruh positif antara Corporate Social Responsibility (CSR) (X1) terhadap

b) Menghitung t-hitung dan signifikansi going concern perusahaan $(\mathrm{Y})$. 
Diketahui :

$t_{\text {-hitung }}=3,133$ dan sig $=0,002$

c) Kriteria Pengujian

- Jika sig < 0,05 maka $\mathrm{H}_{0}$ ditolak, berarti pengaruh tersebut signifikan.

- Jika sig $>0,05$ maka $\mathrm{H}_{0}$ diterima, berartipengaruh tersebut tidak signifikan.

d) Keputusan

Nilai sig lebih kecil dari $<0,05$ sehingga $\mathrm{H}_{0}$ ditolak dan Ha diterima. Ini berarti bahwa Corporate Social Responsibility (CSR) (X1) berpengaruh positif dan signifikan terhadap going concern perusahaan $(\mathrm{Y})$.

\section{Pengaruh Keberadaan Whistleblowing Internal Terhadap Going Concern} Perusahaan.

Uji-t digunakan untuk menguji signifikansi masing-masing koefisien regresi, sehingga diketahui apakah secara parsial Keberadaan Whistleblowing Internal terhadap going concern perusahaan adalah memang nyata terjadi (signifikan) atau hanya diperoleh secara kebetulan. Langkah-langkah uji statistiknya adalah sebagai berikut:

a) Membuat Formulasi Hipotesis

$\mathrm{H}_{0}: \beta_{2}=0 \quad$ Berarti bahwa tidak ada pengaruh yang nyata antara Keberadaan Whistleblowing Internal (X2) terhadap going concern perusahaan $(Y)$.

$\mathrm{Ha}: \beta_{2}>0 \quad$ Berarti bahwa ada pengaruh positif antara Keberadaan Whistleblowing Internal (X2) terhadap going concern perusahaan $(\mathrm{Y})$.

b) Menghitung t-hitung dan signifikansi

Diketahui:

$\mathrm{t}_{\text {-hitung }}=4,225$ dan sig $=0,000$

c) Kriteria Pengujian

- Jika sig < 0,05 maka $\mathrm{H}_{0}$ ditolak, berarti pengaruh tersebut signifikan.

- Jika sig > 0,05 maka $\mathrm{H}_{0}$ diterima, berarti pengaruh tersebut tidak signifikan.

d) Keputusan

Nilai sig lebih kecil dari $<0,05$ sehingga $\mathrm{H}_{0}$ ditolak dan $\mathrm{Ha}$ diterima. Ini berarti bahwa Keberadaan Whistleblowing Internal (X2) berpengaruh positif dan signifikan terhadap going concern perusahaan $(\mathrm{Y})$.

\section{Pengaruh Good Corporate Governance (GCG) Terhadap Going Concern} Perusahaan.

Uji-t digunakan untuk menguji signifikansi masing-masing koefisien regresi, sehingga diketahui apakah secara parsial Good Corporate Governance (GCG) terhadap going concern perusahaan adalah memang nyata terjadi (signifikan) atau hanya diperoleh secara kebetulan. Langkah-langkah uji statistiknya adalah sebagai berikut:

a) Membuat Formulasi Hipotesis

$\mathrm{H}_{0}: \beta_{3}=0 \quad$ Berarti bahwa tidak ada pengaruh yang nyata antara Good Corporate Governance (GCG) (X3) terhadap going concern perusahaan $(\mathrm{Y})$.

$\mathrm{Ha}: \beta_{3}>0 \quad$ Berarti bahwa ada pengaruh

positif antara Good Corporate Governance (GCG) (X3) terhadap going concern perusahaan $(\mathrm{Y})$.

b) Menghitung t-hitung dan signifikansi 
Diketahui:

$\mathrm{t}_{\text {-hitung }}=9,199$ dan $\operatorname{sig}=0,000$

c) Kriteria Pengujian

- Jika sig < 0,05 maka $\mathrm{H}_{0}$ ditolak, berarti pengaruh tersebut signifikan.

- Jika sig $>0,05$ maka $\mathrm{H}_{0}$ diterima, berartipengaruh tersebut tidak signifikan.

d) Keputusan

Nilai sig lebih kecil dari $<0,05$ sehingga $\mathrm{H}_{0}$ ditolak dan Ha diterima. Ini berarti bahwa Good Corporate Governance (GCG) (X3) berpengaruh positif dan signifikan terhadap going concern perusahaan (Y).

\section{PEMBAHASAN}

\section{Pengaruh Corporate Social Responsibility (CSR) (X1) Terhadap Going Concern Perusahaan (Y)}

Berdasarkan hasil analisis regresi linier berganda bahwa Corporate Social Responsibility (CSR) memiliki pengaruh yang positif dan signifikan terhadap going concern perusahaan sebesar 2,427 yang berarti semakin tinggi Corporate Social Responsibility (CSR) maka semakin baik Going Concern Perusahaan Perhotelan. Dengan demikian $\mathrm{H}_{1}$ pada penelitian ini yang menyatakan Corporate Social Responsibility (CSR) berpengaruh positif dan signifikan terhadap Going Concern Perusahaan dapat diterima kebenarannya. Hasil penelitian ini sudah sesuai dengan penelitian yang dilakukan oleh (Ni Nyoman Yudari, 2016).

\section{Pengaruh Keberadaan Whistleblowing Internal (X2) Terhadap Going Concern Perusahaan ( $Y$ )}

Berdasarkan hasil analisis regresi linier berganda bahwa Keberadaan Whistleblowing Internal memiliki pengaruh yang positif dan signifikan terhadap going concern perusahaan sebesar 0,055 yang berarti semakin baik penerapan Keberadaan Whistleblowing Internal perusahaan, maka semakin baik Going Concern Perusahaan Perhotelan. Dengan demikian $\mathrm{H}_{2}$ pada penelitian ini yang menyatakan Keberadaan Whistleblowing Internal berpengaruh positif dan signifikan terhadap Going Concern Perusahaan dapat diterima kebenarannya.

\section{Pengaruh Good Corporate Governance (GCG) (X3) Terhadap Going Concern Perusahaan (Y)}

Berdasarkan hasil analisis regresi linier berganda bahwa Good Corporate Governance (GCG) memiliki pengaruh yang positif dan signifikan terhadap going concern perusahaan sebesar 0,908 yang berarti semakin baik pelaksanaan Good Corporate Governance (GCG), maka semakin baik Going Concern Perusahaan Perhotelan. Dengan demikian $\mathrm{H}_{3}$ pada penelitian ini yang menyatakan Good Corporate Governance (GCG) berpengaruh positif dan signifikan terhadap Going Concern Perusahaan dapat diterima kebenarannya. Hasil penelitian ini sudah sesuai dengan penelitian yang dilakukan oleh (Teguh Heri Setiawan, 2011).

\section{SIMPULAN}

Berdasarkan analisis dan pembahasan di bab IV, maka dapat disimpulkan sebagai berikut:

1. Corporate Social Responsibility (CSR) berpengaruh positif dan signifikan terhadap Going Concern Perusahaan Perhotelan. Dengan demikian penelitian ini menyatakan semakin tinggi Corporate Social Responsibility (CSR) maka semakin baik Going Concern Perusahaan Perhotelan. Hal ini dapat dilihat pada hasil uji-t yang menunjukan nilai t-hitung pada Corporate Social Responsibility (CSR) sebesar, 3,133 dengan nilai signifikansi 0,000<0,05. 
Ini berarti bahwa pengaruh Corporate Social Responsibility (CSR) terhadap Going Concern Perusahaan positif.

2. Keberadaan Whistleblowing Internal berpengaruh positif dan signifikan terhadap Going Concern Perusahaan Perhotelan. Dengan demikian penelitian ini menyatakan semakin baik penerapan Keberadaan Whistleblowing Internal perusahaan, maka semakin baik Going Concern Perusahaan Perhotelan. Hal ini dapat dilihat pada hasil uji-t yang menunjukan nilai t-hitung pada Keberadaan Whistleblowing Internal sebesar, 4,225 dengan nilai signifikansi $0,000<0,05$. Ini berarti bahwa pengaruh Keberadaan Whistleblowing Internal terhadap Going Concern Perusahaan positif.

3. Good Corporate Governance (GCG) berpengaruh positif dan signifikan terhadap Going Concern Perusahaan Perhotelan. Dengan demikian penelitian ini menyatakan semakin baik pelaksanaan Good Corporate Governance (GCG) maka semakin baik Going Concern Perusahaan Perhotelan. Hal ini dapat dilihat pada hasil uji-t yang menunjukan nilai t-hitung pada Keberadaan Whistleblowing Internal sebesar, 9,199 dengan nilai signifikansi 0,000 < 0,05. Ini berarti bahwa pengaruh Good Corporate Governance (GCG) terhadap Going Concern Perusahaan positif.

Berdasarkan hasil penelitian serta simpulan, adapun saran yang dapat diberikan untuk penelitian ini adalah sebagai berikut :

1. Sebaiknya perusahaan perhotelan yang terdaftar di BEI menerapkan Corporate Social Responsibility (CSR) secara konsisten guna mengurangi dampak negatif berupa pencemaran lingkungan yang dihasilkan.

2. Untuk perusahaan yang sudah menerapkan CSR, sangat disarankan untuk membuat sustainability report dengan pengungkapan sesuai Global Reporting Initiative (GRI). Global Reporting Initiative (GRI) adalah organisasi non-pemerintah yang mengembangkan dan menyebarluaskan Pedoman Pelaporan Keberlanjutan yang berlaku secara global.

3.

Sebaiknya penerapan Whistleblowing dalam internal perusahaan lebih diperhatikan, khususnya pada perusahaan yang belum menerapkan Whistleblowing dalam internal perusahaan. Dengan menerapkan Whsitleblowing maka dapat mencegah tindak kecurangan dalam perusahaan secara efektif sehingga dapat menjaga going concern perusahaan.

4. Disarankan untuk perusahaan yang sudah menerapkan Whistleblowing, sebaiknya membuat pelaporan pelaksanaan Whistleblowing sesuai standar Komite Nasional Kebijakan Gonvernance (KNKG) mengenai Sistem Pelaporan Pelanggaran Whistleblowing System (SPP-WBS).

5. Penerapan Good Corporate Governance (GCG) secara konsisten sangat disarankan, karena Good Corporate Governance secara efektif dapat memberikan perlindungan kepada pemegang saham maupun kreditur dan untuk menjamin pengembalian atas investasinya dengan hasil yang tinggi.

\section{REFERENSI}

Armini, Putu Yunita. 2019. "Pengaruh Penerapan Green Accounting, Dan Kinerja Lingkungan Terhadap Kinerja Keuangan Pada Perusahaan Manufaktur Di Bursa Efek Indonesia Tahun 2016-2018"

Balmy, Widyo Putri. 2013. "Pengaruh Corporate Social Responsibility Disclosure Index (CSRDI) Terhadap Harga Saham (Studi Kasus Pada Perusahaan Manufaktur Dan Pertambangan Yang Tercatat Dalam Index Lq45 Periode Februari - Juli 2012)."

Bertuah.co.id, 2017. Prinsip-Prinsip GCG. Retrived from https://bertuah.co.id/prinsipprinsip-gcg/

Bursa Efek Indonesia, www.idx.co.id diakses pada 1 Agustus 2020 
Estate dan Property yang Terdaftar Di Bursa Efek Periode 2010-2014 Indonesia." Universitas Muhammadiyah Surakarta.

Falensy, Devina. 2018. "Pengaruh Corporate Social Responsibility Terhadap Kinerja Keuangan Pada Perusahaan Perhotelan Yang Terdaftar Di BEl."

Hestanto, PersonalWeb. (2019) Teori Agensi (Agency Theory). Retriedved from https://www.hestanto.web.id/teori-keagenan-agency-theory/

Jurnal Manajemen. (2009). Pengantar Perhotelan: Definisi Hotel, Karakteristik dan Jenis. Retrived from http://jurnal-sdm.blogspot.com/2009/07/pengantar-perhotelan-definisihotel.html/

KNKG-Indonesia.org. (2008). Pedoman Pelaporan Whistleblowing. Retrived from http://www.knkg-indonesia.org/dokumen/Pedoman-Pelaporan-Pelanggaran-WhistleblowingSystem-WBS.pdf

Kurniawati, Tria, dan CA dr. Erma Setyowati, M.M.,Akt. 2015. "Pengaruh Reputasi Auditor, Disclosure, Audit Client Tenure, Dan Ukuran Perusahaan Terhadap Opini Audit Going Concern (Studi Empiris pada Perusahaan Real

Kusmawan, Reynaldi Mulyana. 2019. "Pengaruh Pemahaman Risk Based Internal Audit, Whistleblowing System, Kesadaran Anti-Fraud, dan Penerapan Prinsip-Prinsip Good Corporate Governance Terhadap Pencegahan Fraud Pada Bank Perkreditan Rakyat di Provinsi Bali.

Mayasari, Mega, Adi Irawan Setiyanto, dan Irawati Rusda. 2018. "Pengaruh Faktor-Faktor Individual Terhadap Niat Melakukan Whistle-Blowing Internal Dan Eksternal Pada Akuntan Di Batam (Studi Kasus Politeknik Negeri Batam)." Politeknik Negeri Batam.

Premashanti, Ni Made Niki. 2019. "Pengaruh Reputasi Kantor Akuntan Publik, Keberadaan Komite Audit, Dan Prior Opinion Terhadap Pemberian Opini Audit Going Concern Pada Perusahaan Manufaktur Di Bursa Efek Indonesia Periode 2014-2015."

Prena, Gine Das. 2012. "6. Pengaruh Keberadaan Komisaris Independen Sebagai Bagian Penerapan Board Of Directors (Implementasi Good Corporate Governance) Terhadap Konservatisme Pelaporan Keuangan."

Prena, Gine Das, dan Komang Wahyu Diarsa. 2018. "Pengaruh Kinerja Keuangan Dan Nilai Perusahaan Terhadap Keberlanjutan Usaha (Going Concern) Pada Perusahaan Perbankan Di Bursa Efek Indonesia (BEl)." Fakultas Ekonomi dan Bisnis Universitas Pendidikan Nasional (Undiknas).

Prena, Gine Das, Putu Purnama Dewi, Ketut Tanti Kustina, IGA Agung Omika Dewi, dan I Nengah Wirsa. 2019. "Pengaruh Eco Efficiency, Corporate Social Responsibility Dan Accrual Quality Terhadap Nilai Perusahaan (Perusahaan Manufaktur Di Bursa Efek Indonesia Tahun 2016 - 2018)."

Rendi, Muhammad Ihsan. 2016. "Pengaruh Good Corporate Governance Dan Pengungkapan Corporate Social Responsibility Terhadap Nilai Perusahaan (Studi Pada Perusahaan yang Terdaftar di Bursa Efek Indonesia yang Mengikuti Program 
Pemeringkatan Corporate Governance Perception Index Periode." Fakultas Ekonomi Unpas, no. 114020294.

Santoso, Wibowo, Yokhebed, dan DR Tampubolon Lambok. 2015. "Pengaruh CSR Disclosure Dan GCG Terhadap Nilai Perusahaan Dengan Kinerja Keuangan Sebagai Variabel Intervening Di Perusahaan Manufaktur Yang Terdaftar Di Bursa Efek Indonesia (2012-2014)."

Sea Rowa, Carolina. 2019. "Pengaruh Pengungkapan Corporate Social Responsibility Terhadap Penerimaan Opini Audit Going Concern Pada Perusahaan Tambang Tahun 20162017." 